
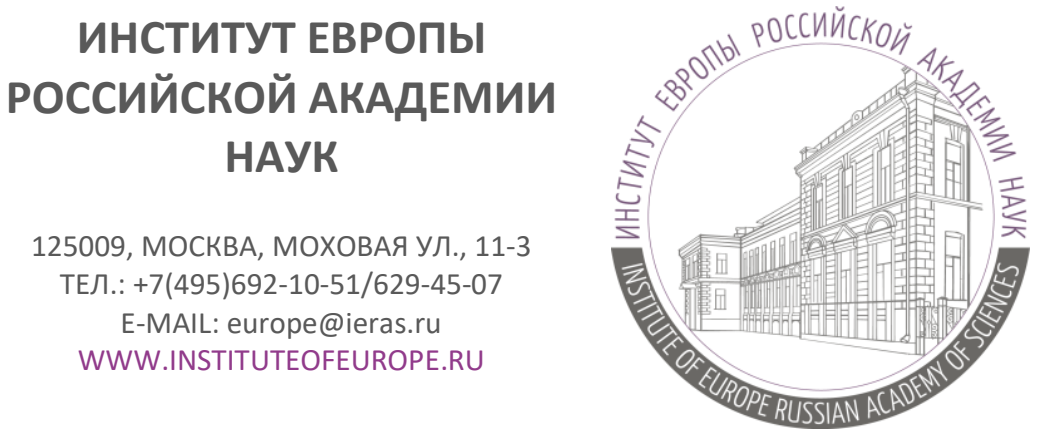

\section{INSTITUTE OF EUROPE RUSSIAN ACADEMY OF SCIENCES}

125009, MOSCOW, MOKHOVAYA STR., 11-3

TEL.: +7(495)692-10-51/629-45-07

E-MAIL: europe-ins@mail.ru WWW.INSTITUTEOFEUROPE.RU

\author{
Аналитическая записка №28, 2020 (№211) ${ }^{1}$
}

\title{
Старт торговых переговоров США и Великобритании
}

\section{Кира Анатольевна Годованюк}

кандидат политических наук, старший научный сотрудник Центра британских исследований Института Европы РАН

\begin{abstract}
Аннотация В начале мая 2020 года в онлайн-режиме начались переговоры между США и Великобританией по Соглашению о свободной торговле. Эта сделка, призванная укрепить «особые отнотения» двух стран, может столкнуться с серьезным вызовом в виде американского протекичонизма в рамках кониепичи America First. B то же время Кабинет Соединенного Королевства, ориентированный на самостоятельную торговую политику после брекзита, заинтересован безотлагательно продемонстрировать успехи нового курса. Компромиссом для обеих сторон могла бы стать мини-сделка, которая будет регулировать лишь частные вопросы двусторонней торговли, но станет имиджевым ходом для правительств двух стран.
\end{abstract}

Ключевые слова: «особые отночения» США и Великобритании, Согламение о свободной торговле, брекзит, EC, тарифы, технические стандарты, экспорт, мини-сделка, пандемия COVID-19.

\section{Политические мотивы торгового соглашения}

5 мая 2020 года начались переговоры по соглашению о свободной торговле между США и Великобританией. В первом раунде консультаций приняли участие около 30

\footnotetext{
${ }^{1}$ DOI: http://doi.org/10.15211/analytics 282020
} 
рабочих групп, которые обсудили взаимодействие в сфере малого и среднего бизнеса, вопросы налогообложения, таможенного контроля, инвестиций, устранения технических торговых барьеров. С 15 июня начался второй двухнедельный раунд переговоров. В связи с продолжающейся пандемией COVID-19 консультации проходят в режиме видеоконференции ${ }^{2}$.

Взаимовыгодное соглашение между двумя ближайшими союзниками было одним из предвыборных обещаний правительства брекзитеров. Противники выхода страны из Европейского союза использовали в качестве политического козыря предостережение Б. Обамы: «в случае брекзита Лондон окажется последним в очереди на торговое соглашение с США» ${ }^{3}$. Для президента Д. Трампа сделка с Великобританией - вызов своему предшественнику-демократу. Не менее важно для нынешнего главы Белого дома (сторонника брекзита) поддержать самостоятельный внешнеэкономический курс Соединенного Королевства в пику Брюсселю. В октябре 2018 г. администрация Д. Трампа уведомила Конгресс о намерении заключить три торговых соглашения с ЕС, Японией и Великобританией ${ }^{4}$.

В Соединенном Королевстве сразу после референдума развернулись дискуссии о целесообразности сделки с новой администрацией Белого дома, которая в рамках установки America First продвигает собственные политические и торговые интересы зачастую за счет контрагентов. Однако для Лондона, который теряет влияние на европейском направлении, укрепление связей с Вашингтоном - политическая демонстрация союза, который может получить и экономико-правовую основу. Страны, несмотря на некоторые расхождения в подходах к современным международным отношениям ${ }^{5}$, взяли курс на полномасштабную торговую сделку. Британский политический истеблишмент рассчитывает представить соглашение как первый крупный успех независимой от Брюсселя внешнеторговой политики.

На фоне явной политизации британо-американского соглашения, стороны апеллируют и к экономической выгоде. Так, согласно заявлению министра международной торговли Соединенного Королевства, укрепление трансатлантических связей обеспечит странам выход из рецессии, вызванной пандемией COVID- $19^{6}$.

\footnotetext{
${ }^{2}$ UK and US start trade negotiations. May 5, 2020. URL: https://www.gov.uk/government/news/uk-and-us-starttrade-negotiations (дата обращения: 15.06.2020)

${ }^{3}$ Cameron 'personally requested Obama's back of the queue Brexit warning'. URL: https://news.sky.com/story/c ameron-personally-requested-obamas-back-of-the-queue-brexit-warning-11423669 (дата обращения: 15.06.2020)

${ }^{4}$ Trump Administration Announces Intent to Negotiate Trade Agreements with Japan, the European Union and the United Kingdom. URL: https://ustr.gov/about-us/policy-offices/press-office/pressreleases/2018/october/trump-administration-announces (дата обращения: 15.06.2020)

5 Главный лозунг администрации Д. Трампа - «американизм, а не глобализм» (Americanism, not globalism, will be our credo). Правительство консерваторов после прекращения членства страны в ЕС взяло курс на «Глобальную Британию», новый внешнеполитический курс на основе неолиберальных ценностей и «лучших достижений глобализации». Исследователи сходятся во мнении, что голосование за брекзит следует рассматривать как протест электората против «негативных последствий глобализации».

${ }^{6}$ UK government begins transatlantic trade talks with Washington. URL: https://www.theguardian.com/business /2020/may/04/uk-government-begins-transatlantic-trade-talks-with-washington (дата обращения: 15.06.2020)
} 


\section{Торговые интересы сторон}

Вашингтон - второй торговый партнер Лондона, на который приходится пятая часть британского экспорта. Объем торговли в 2018 г. составил 201,6 млрд ф.ст. ${ }^{7}$, что многократно уступает совокупному объему торговли со странами ЕС (659,5 млрд ф.ст.).

США продают своему союзнику самолеты, драгоценные металлы, минеральное топливо, электрооборудование. Основные экспортные товары Британии - автомобили, фармацевтическая продукция, а также некоторая продукция сельского хозяйства (сыр, красное мясо). Великобритания экспортирует за океан услуги в сфере финансов, транспорта и путешествий. В 2017 г. американские инвестиции составляли почти четверть от всех прямых иностранных инвестиций в Великобритании.

2 марта 2020 года Департамент международной торговли Соединенного Королевства обнародовал цели торговых переговоров с Вашингтоном. Британия рассчитывает облегчить доступ для своих промышленных и сельскохозяйственных товаров на американский рынок за счет снижения тарифных барьеров (британский сыр «Чеддер» сегодня облагается тарифами в 17,6\%). Великобритания также заинтересована облегчить доступ к американскому рынку бухгалтерских и финансовых услуг.

В феврале 2019 г. Торговое представительство США представило приоритеты в отношении британо-американской сделки ${ }^{8}$. Белый дом тоже надеется упростить доступ для своих промышленных и сельскохозяйственных товаров, что означает устранение тарифных и нетарифных барьеров (понижение британских технических стандартов). Сегодня в Великобритании действуют более строгие (установленные ЕС) экологические, санитарные и фитосанитарные нормы. США рассчитывают, что продукция американских фермерских хозяйств будет беспрепятственно поступать на британские прилавки. В Соединенном Королевстве, однако, развернулись дискуссии об опасности американской «хлорированной» курятины и говядины с добавлением гормонов. США называют стандарты Евросоюза «плохо прикрытым протекционизмом».

Вашингтон, в отличие от Лондона, установил минимальные показатели энергоэффективности, страны расходятся и в нормах выбросов парниковых газов. Установлены разные тарифы в отношении импортируемых промышленных товаров. Например, американские тарифы на автомобили составляют 2,5\%, в то время как в Великобритании - 10\%. США, очевидно, будут ожидать, что Лондон пойдет на значительные уступки.

\footnotetext{
${ }^{7}$ UK Trade in Numbers February, 2020.

URL: https://assets.publishing.service.gov.uk/government/uploads/system/uploads/attachment_data/file/868378/ 200227_UK_trade_in_Numbers_full_web_version_final.pdf (дата обращения: 30.05.2020)

${ }^{8}$ United States-United Kingdom Negotiations Summary of Specific Negotiating Objectives February 2019. URL: https://ustr.gov/sites/default/files/Summary_of_U.S.-UK_Negotiating_Objectives.pdf (дата обращения: 20.06.2020)
} 
Вашингтон также рассчитывает добиться полного доступа для американских фармацевтические компаний к британскому рынку, включая продление патентов с правом влиять на ценообразование, что приведет к подорожанию медикаментов. Правительство Великобритании неоднократно заявляло, что национальная система здравоохранения не подлежит торгу, США, вероятно, не оставят попытки добиться искомого.

С началом торговых переговоров на повестку вышли вопросы налогообложения в сфере цифровых услуг. 6 июня Вашингтон начал специальное расследования в отношении налоговых систем в 10 юрисдикциях, включая Британию, ряд стран Евросоюза, а также Турцию, Бразилию, Индию и Индонезию, где введен специальный налог с продаж цифровых услуг ${ }^{9}$. США считают подобное решение нечестной конкуренцией и угрожают увеличить тарифы, например, на британские автомобили ${ }^{10}$. Американская сторона планирует выработать ряд штрафных мер, направленных на «защиту национального бизнеса от дискриминации».

\section{Переговорная стратегия Соединенного Королевства}

Британское правительство избрало особую переговорную тактику: согласования проходят параллельно с несколькими партнерами. 17 июня Б. Джонсон объявил о начале торговых переговоров с Новой Зеландией и Австралией. Некоторые эксперты критикуют тактику Кабинета, поскольку она осложняет правительственную координацию между разными командами переговорщиков.

Следует иметь в виду, что британо-американские консультации неотделимы от переговоров Лондона и Брюсселя по условиям торговли постбрекзит, ведь требования США противоречат правилами и нормативами ЕС. Эксперты отмечают, что британское правительство стремится использовать экономические противоречия в треугольнике Лондон-Брюссель-Вашингтон как рычаг давления на ЕС (классический прием теории игр) ${ }^{11}$. Брюссель был бы в более удобной переговорной позиции, если бы британоамериканский договор не стоял на повестке.

Экономисты, однако, сомневаются, что Соединенному Королевству удастся убедить Евросоюз отказаться от его условий: нулевые квоты и отсутствие тарифных и нетарифных барьеров возможно только при сохранении единых стандартов. Учитывая, что британский бизнес крайне заинтересован в преференциальных условиях выхода на общеевропейский рынок, Лондону необходимо будет проявлять гибкость.

По расчетам правительства Соединенного Королевства, обнародованным еще в 2018 г., торговая сделка с Вашингтоном, вероятно, принесет весьма ограниченные

\footnotetext{
${ }^{9}$ 01.04.2020 в Британии введен новый налог (2\%) с продаж цифровых услуг для компаний с годовой выручкой от 500 млн ф.ст. Под него подпадают американские гиганты Alphabet, Facebook, Apple и др.

${ }^{10}$ US takes aim at digital services taxes in UK and EU. URL: https://www.ft.com/content/e8edf57b-f87f-439eac1d-56ba28a96b78 (дата обращения: 20.06.2020)

${ }^{11}$ Trade triangle: U.S., Britain, and European Union. URL: https://www.politico.com/news/2020/06/14/tradetriangle-us-britain-and-european-union-319211 (дата обращения: 15.06.2020)
} 
экономические дивиденды ${ }^{12}$. Исследования показывают, что преференциальные торговые соглашения с США и странами Содружества наций не помогут Британии компенсировать негативный экономический эффект от брекзита ${ }^{13}$.

Вероятно, Лондон и Вашингтон двигаются в направлении мини-соглашения (подобно британо-китайской или британо-японской сделке ${ }^{14}$ ). В американском законодательстве для таких соглашений предусмотрен быстрый процесс согласования (fast-track approvals process), который не требует одобрения конгрессменов. Для Д. Трампа новые международные торговые соглашения становятся частью его избирательной кампании. Однако накануне президентских выборов в США полномасштабное соглашение с Лондоном может стать заложником внутриполитической борьбы.

Если мини-сделка будет предполагать лишь снятие квот и тарифных ограничений по ряду товаров и не потребует от Британии существенного понижения технических стандартов, Лондон сохранит поле для маневра на переговорах с Брюсселем. Однако главный переговорщик от США подтвердил, что Вашингтон рассчитывает согласовать полномасштабное торговое соглашение, которое будет рассматривать Конгресс ${ }^{15}$.

\section{Выводы}

Нет оснований полагать, что стороны смогут заключить полномасштабную сделку до окончания переходного периода. Экономические последствия от пандемии COVID-19 на фоне предвыборной кампании в США, скорее всего, осложнят виртуальные переговоры. К факторам, осложняющим двусторонние отношения, следует также отнести негативный рейтинг Д. Трампа в Великобритании, усиление внутриполитической борьбы накануне президентских выборов.

Параллельно Лондон договаривается о параметрах сделки с Брюсселем. Игра Британии на противоречиях в технических стандартах двух потенциальных партнеров, может в итоге дать нулевой результат. Очевидный дрейф в сторону американских правил осложнит торговлю с ЕС, а шанс заключить Соглашение о свободной торговле с ним в ближайшей перспективе будет утрачен. Великобритании, вероятно, придется искать более гибкий подход к переговорам с потенциальными партнерами.

Компромиссом могла бы стать мини-сделка с США, которая будет регулировать лишь частные вопросы двусторонней торговли, но станет имиджевым ходом для правительств двух стран.

\footnotetext{
${ }^{12}$ EU Exit Long term economic analysis November 2018. URL: https://assets.publishing.service.gov.uk/governm ent/uploads/system/uploads/attachment_data/file/760484/28_November_EU_Exit_-_Longterm_economic_analysis__1_.pdf (дата обращения: 15.06.2020)

${ }^{13}$ Post Brexit trade survival: looking beyond the European Union. URL: https://core.ac.uk/download/pdf/159034 532.pdf (дата обращения: 15.06.2020)

${ }^{14}$ Сделка, подписанная в октябре 2019 г., предусматривает снятие тарифных барьеров для американской фермерской продукции и отдельных промышленных товаров из Японии. FACT SHEET on U.S.-Japan Trade Agreement. URL: https:/ustr.gov/about-us/policy-offices/press-office/fact-sheets/2019/september/factsheet-us-japan-trade-agreement (дата обращения: 15.06.2020)

${ }^{15}$ US says a UK trade deal 'unlikely' before November. URL: https://www.bbc.com/news/business-53084467 (дата обращения: 20.06.2020)
} 


\begin{abstract}
Early May 2020 saw the start of the UK-US online trade negotiations. The deal was designed as a new milestone of the "special relationship". But the negotiations seem to face a serious challenge caused by the US protectionism as the inherent part of the America First concept. In the meantime, the UK government wants to demonstrate a quick success of its foreign economic policy. There is a possibility that the negotiating parties in London and Washington may compromise on a mini-deal, which regulates some particular trade issues, serving at the same time as a symbol of the strong special relationship.
\end{abstract}

Key words: UK-US special relationship, free trade agreement, Brexit, EU, tariffs, technical regulation, quotas, export, mini-deal, COVID-19 pandemic.

Дата выпуска: 26 июня 2020 года.

Материал доступен для скачивания по адресу: www.instituteofeurope.ru/publications/analytics 